\title{
Boron isotope systematics in the magmatic evolution of San Pedro and La Poruña volcanoes, Central Andes, northern Chile.
}

\author{
BENIGNO GODOY ${ }^{1}$, PETRUS LE ROUX ${ }^{2}$, FRANCES \\ DEEGAN $^{3}$, DIETER GARBE-SCHÖNBERG ${ }^{4}$, DR. OSVALDO \\ GONZÁLEZ-MAUREL, PHD ${ }^{2}$ AND INÉS RODRÍGUEZ ${ }^{5}$ \\ ${ }^{1}$ Centro de Excelencia en Geotermia de los Andes (CEGA), \\ Universidad de Chile \\ ${ }^{2}$ University of Cape Town \\ ${ }^{3}$ Uppsala University \\ ${ }^{4}$ CAU Kiel University \\ ${ }^{5}$ Universidad Católica de Temuco \\ Presenting Author: bgodoy@uchile.cl
}

Boron is fluid mobile and incompatible in most magmatic processes, making it an excellent tracer of mass transfer in subduction zones. Moreover, boron isotopes are not fractionated during magmatic differentiation (fractional crystallisation), which makes them useful in determining crustal additions to magma during ascent through the crust.

We present boron isotope data $(\mathrm{n}=10)$ for lava samples from La Poruña scoria cone $(<100 \mathrm{ka})$ and San Pedro stratovolcano $(<$ $160 \mathrm{ka})$ in the Central Andean volcanic arc, where crustal contamination plays a key role in magmatic evolution [e.g. 1,2]. At La Poruña, a trend of decreasing ${ }^{87} \mathrm{Sr} /{ }^{86} \mathrm{Sr}$ as differentiation increases defines assimilation during a turbulent ascent process [1]. Similarly, at San Pedro, the young lavas ( $<100 \mathrm{ka})$ are less differentiated than the older San Pedro (100-160 ka) series but the young lavas also show ${ }^{87} \mathrm{Sr} /{ }^{86} \mathrm{Sr}$ values that suggest higher degrees of crustal assimilation [1]

Our results show relatively low $\delta^{11} \mathrm{~B}$ values for both La Poruña $(-1.4 \%)$ and San Pedro (-0.6 \%o) samples that also record the highest degrees of crustal contamination of the studied lava suite $\left({ }^{87} \mathrm{Sr} /{ }^{86} \mathrm{Sr}\right.$ ratios $\left.>0.7066\right)$. This is consistent with a model involving mixing between a) a parental arc magma hydrated with fluid from the Altered Oceanic Crust and b) the Paleozoic Andean crust $\left(\delta^{11} \mathrm{~B}=-8.9 \% ;{ }^{87} \mathrm{Sr} /{ }^{86} \mathrm{Sr}=0.71428\right.$ [3] $)$. Notably, the lowest $\delta^{11} \mathrm{~B}$ value reported here $(-2.1 \%)$ is related to a mafic recharge event $\left({ }^{87} \mathrm{Sr} /{ }^{86} \mathrm{Sr}=0.7062\right)$ occurring during the evolution of San Pedro during its older eruptive stage at $>96 \mathrm{ka}$ [1].

REFERENCES

[1]González-Maurel, Godoy, le Roux, Rodríguez, Marín, Menzies, Bertín, Morata \& Vargas (2019). Lithos, 338-339:128140

[2]Godoy, McGee, González-Maurel, Rodríguez, le Roux, Morata \& Menzies (2020). J S Am Earth Sci, 102:102672.

[3]Rosner, Erzinger, Franz \& Trumbull (2003). Geochem Geophy Geosy, 4(8):9005 